\title{
RESISTENSI MASYARAKAT TERHADAP PERBANKAN SYARI'AH DI KOTA LANGSA
}

\author{
Muhammad Dayyan \\ IAIN Zawiyah Cot Kala Langsa \\ dayyanyusuf@gmail.com
}

\begin{abstract}
.
The presence of Islamic Banking in Langsa since 2005 is in line with the aspirations of the Acehnese as an application of Islamic law. In this case the economic and finance tailored to the sharia is to establishe the people to be compete constructively in favor and the successful life such as happiness, glory, and the hereafter (falah). This things is to realized the shariah goal (maqashid sharia) especially in dharuriah five dimensions, such as: religion, life, thought, ancestry, and wealth. The Islamic banks has established in Langsa since 14 years ago, but the people in Langsa not yet fully trust the operational of Islamic banks. They think there is no difference between Islamic banks and conventional banks, beside using sharia label only. The people that become a conventional bank's customer has a perception that either the Islamic banks or conventional banks still contains a riba.
\end{abstract}

Keywords: resistence; Islamic banks; riba

\begin{abstract}
Abstrak.
Kehadiran perbankan syariah di Kota Langsa sejak tahun 2005 sangat sejalan dengan aspirasi masyarakat Aceh sebagai daerah penerapan syariat Islam secara menyeluruh. Dalam hal ini ekonomi dan keuangan disesuaikan dengan syariah untuk melahirkan masyarakat yang berkompetisi secara konstruktif dalam kebaikan dan kesuksesan hidup yaitu kebahagiaan dan kemuliaan dunia serta akhirat (falah). Hal ini untuk merelisasikan tujuan syariah (maqashid syariah) terutama dalam lima dimensi dharuriah untuk terpeliharanya agama, jiwa, akal, keturunan, dan harta. Perbankan syariah telah 14 tahun beroperasi di Kota Langsa, namun masyarakat Kota Langsa belum sepenuhnya percaya pada perbankan yang menjalankan sistem keuangan dengan memakai label syariah terutama dalam pembiayaan yang dianggap sama dengan lembaga keuangan konvensional. Masyarakat yang menjadi nasabah bank konvensional mempersepsikan bahwa tidak ada perbedaan antara lembaga keuangan syariah ataupun konvensional yang sama-sama tidak terbebas dari riba.
\end{abstract}

Kata Kunci: resistensi; perbankan syariah; riba.

Diterima: 15 Juni 2016; Direvisi: 31 Agustus 2016; Disetujui: 19 September 2016 


\section{PENDAHULUAN}

Kehadiran perbankan Syariah di Kota Langsa sejak tahun 2005 diharapkan memberi solusi terhadap dominasi ekonomi ribawi. Kehadirannya tentu akan memberikan alternatif jalan keluar yang terbaik secara mashlahat bagi perekonomian ummat di Kota Langsa, Aceh Timur dan Aceh Tamiang. Sebagaimana misi utama lembaga keuangan Islam yaitu membebaskan riba dalam seluruh produknya baik dalam menghimpun dana melalui tabungan maupun dalam pembiayaan (Tim Pengembangan Perbankan Syariah IBI, 2003).

Kehidupan ekonomi modern hari ini secara dominan digerakkan oleh ekonomi berbasis sektor keuangan yang cenderung berorientasi pada keuntungan dalam bentuk materil saja. Secara mainstrem lembaga bisnis seperti perbankan cenderung melipatgandakan keuntungan dan menghindari resiko (zero tolerance). Bahkan keuntungan kerap diperoleh bukan dari aktivitas investasi dengan usaha produktif barang dan jasa melainkan dengan investasi spekulatif dan transaksi derivatif berisiko tinggi namun menjanjikan keuntungan melimpah. Dengan kata lain menangguk keuntungan bukan melalui kreativitas dan kerja keras, melainkan melalui kegiatan ekonomi non-riil yang mengabaikan prinsip keadilan. Dikatakan tidak adil karena keuntungan sering dinikmati oleh segelintir orang. Tak heran pertumbuhan ekonomi yang dihasilkan pun tidak berkualitas, hanya sedikit menyerap tenaga kerja, dan menguntungkan kelompok atas yang umumnya tinggal di perkotaan.

Kehadiran Lembaga Keuangan Syariah (LKS) membawa misi untuk merealisasikan maqashid shari'ah (tujuan shari'ah) dalam kegiatan ekonomi yaitu menghilankan riba, gharar, judi, dan kecurangan lainnya dalam sistem ekonomi. Tentu hal tersebut sejalan dengan aspirasi masyarakat Aceh yang telah mendeklarasikan diri sebagai daerah penerapan syari'at Islam secara kaffah. Kehadiran LKS di Aceh khususnya Kota Langsa adalah suatu keniscayaan menggantikan dominasi sistim riba yang diperankan Lembaga Keuangan Konvensional (LKK). Di Kota Langsa, LKS baru ada sejak tahun 2005 dengan dibukanya kantor cabang Bank Syariah Mandiri (BSM), kemudian diikuti oleh Bank Muamalah Indonesia (BMI) pada tahun 2006, Bank Aceh Syariah dan Bank Pembiyaan Rakyat Syariah (BPRS) Syariah Adeco pada tahun 2009. Perbakan 
syariah tersebut diharapkan dapat mendorong masyarakat untuk menghindari riba dengan melahirkan praktek ekonomi dan keuangan sesuai dengan syari'ah. Kegiatan bisnis yang berkonpetisi secara konstruktif akan mendatangkan kebaikan dan kesuksesan hidup yaitu kebahagiaan dunia dan akhirat.

Namun setelah beberapa tahun berjalan ternyata masih banyak masyarakat belum mau menjadi nasabah bank syariah tersebut. Meskipun ada sebagian masyarakat yang menjadi nasabah pada perbankan syariah, namun masih mempertahankan tabungannya pada bank konvensional. Bahkan sebagian besar masyarakat belum bersedia menjadi nasabah bank syariah. Resistensi masyarakat kota Langsa terhadap perbankan syariah tentu sesuatu yang bertolak belakang dengan fakta bahwa hampir seluruh penduduk Aceh adalah penganut ajaran Islam yang fanatik ditambah lagi adanya kebijakan penerapan syariat Islam secara formal di Aceh sejak tahun 2001. Lalu mengapa masyarakat kota Langsa belum sepenuhnya mau menjadi nasabah perbankan Syariah? Menarik untuk mengkaji motif mengapa masyarakat kota Langsa belum sepenuhnya bermuamalah dengan LKS.

Telah terdapat beberapa penelitian yang meneliti perbankan syariah. Khalid (2002) menemukan bahwa persepsi masyarakat Bogor tentang Bank Islam di Kabupaten Bogor masih pada kategori sedang (50.8\%) untuk kategori nasabah bank syariah sedangkan kategori non Nasabah mempersepsikan bank Islam dengan kategori jelek atau 81.6\% dari total 40 responden. Daulay (2014) mengalisis faktor-faktor yang mempengaruhi persepsi masyarakat Propinsi Banten terhadap perbankan Syariah menyimpulkan bahwa faktor yang paling dominan yang mempengaruhi persepsi masyarakat Banten terhadap Bank Syariah adalah penerapan konsep bagi hasil dalam perbankan syariah. Sementara itu Mu'allim (2003) menemukan bahwa keduanya memilih bank syariah karena kriteria pelayanan yang cepat dan efisien yang menempati ranking satu dibandingkan alasannya lainnya seperti kredibilitas bank, istilah pembiayaan, maupun bagi hasilnya. Usman (2015) menemukan bahwa faktor agama masih menjadi salah satu penentu dalam memilih bank syariah. 


\section{METODE}

Kajian ini difokuskan untuk menjawab dan mengulas pertanyaan diatas dengan menggunakan pendekatan deskriptif. Informasi atau data-datanya diperoleh dengan cara kuisioner, wawancara. Data kepustakaan berupa kitabkitab, buku, jurnal ilmiah, sebagai sumber utama dalam merumuskan teori, memperkuat argument dan analisis terhadap hasil yang diperoleh di lapangan. Pelaksanaan survey dengan penyebaran kuisioner dilakukan selama sebulan yaitu dari 25 Juli 2013 sampai dengan 25 Austus 2013 dengan mendatangi masyarakat diberbagai tempat antara lain di kampus, mesjid, toko-toko, kedai kopi, dan kantor bank syariah. Kuisioner yang disebarkan sebanyak 300 (tiga ratus) eksemplar, namun yang mengisi dan mengembalikan sebanyak 116 (seratus enam belas) responden yang terdiri dari mahasiswa, akademisi, pedagang, politisi, dan lain-lain yang sudah menjadi nasabah bank. Jumlah 116 dipandang sudah memadai dan mencukupi untuk dijadikan sampel yang kemudian hasilnya dianalisa dalam bentuk deskriptif analitik. Yaitu memberikan gambaran atau uraian atas suatu keadaan sejelas mungkin tanpa ada perlakuan terhadap objek yang diteliti.

Kuisioner dalam kajian ini menkombinasikan model pertanyaan tertutup dan terbuka untuk mendapatkan jawaban responden secara lebih fleksibel. Keseluruhan pertanyaannya disiapkan pilihan jawaban yang harus dipilih oleh responden. Selanjutnya untuk menguji validitas penulis menggunakan pertanyaan terbuka yang bisa dijawab oleh responden secara bebas. Kemudian ditambah dengan wawancara dengan para pakar dan ahli hukum Islam terkait dengan simtim keuangan Islam.

\section{HASIL DAN PEMBAHASAN}

Latar belakang responden secara keseluruhan dari kajian ini sebanyak 213 orang yang terdiri dari 141 laki-laki atau 66 persen lebih dan 72 perempuan atau hampir 34 persen. Ini menunjukkan laki-laki lebih mudah ditemui dan lebih banyak berhubungan dengan lembaga keaungan. Namun demikian ini tidak menunjukkan kepada kita bahwa perempuan tidak suka menabung karena penelitian ini lebih fokus pada nasabah yang mengambil pembiayaan dengan lebaga keuangan syariah. Dilihat dari segi umur 30 persen responden berusia 
antara 30 - 35 dan 21 persen responden berusia 35 tahun keatas selebihnya 48 persen berumur antara 18 - 29 tahun. Artinya para responden sudah memiliki rekening sejak menjadi pelajar dan mahasiswa. Hal ini dapat dilihat juga pada profesi responden banyak dari kalangan muda. Namun jika dilihat dari status perkawinan 60 persen lebih sudah berkeluarga atau sudah menikah.

Menariknya sebagian besar masyarakat yang telah menjadi nasabah lembaga keuangan syariah masih tetap menjadi nasabah lembaga keuangan konvensional atau sebanyak 46 persen, dan 30 persen mereka hanya menjadi nasabah lembaga keuangan syariah dan selebihnya atau 23 persen sebagai nasabah lembaga keuangan konvensional saja. Selanjutnya dilihat dari jumlah tabungan secara mayoritas atau 38.5 \% menjawab dibawah Rp. 2.000.000,selanjutnya 30\% jumlah tabungan antara Rp. 2.100.000 - Rp 5.000.000, dan selebihnya diatas Rp.5.000.000. Kemudian dari total 95 responden yang mengambil pembiayaan produktif pada lembaga keuangan syariah, dengan ratarata diatas 20\% memiliki hutang modal dari Rp. 20.000.000 sampai Rp. 150.000.000 dan hanya 4 \% mengambil pembiayaan diatas Rp.150.000.000,-.

Sementara itu nasabah yang mengambil pembiayaan konsumtif pada lembaga keuangan syariah lebih banyak yaitu 114 dari 213 responden. Dari jumlah itu sebanyak 28\% atau 32 orang memiliki kredit antara Rp.21.000.000 Rp.50.000.000. Selanjutnya 24.6\% mengambil pembiayaan dibawah Rp.20.000.000,- hal ini hampir sama dengan yang mengambil pembiayaan sebanyak antara Rp.51.000.000 - Rp. 100.000.000,- yaitu 25.4\%. Hanya 5\% yang mengambil pembiayaan diatas Rp.150.000.000,- dan selebihnya atau $16.7 \%$ memiliki kredit antara Rp.110.000.000 - Rp.150.000.000.

Perkembangan lembaga keuangan sangat dipengaruhi oleh tingkat partisipasi masyarakat dalam menabung dan mengambil pembiayaan untuk dijadikan modal usaha atau biaya konsumtif sehingga lembaga tersebut dapat menambah keuntungannya. Bahwa ada sejumlah persepsi yang mempengaruhi masyarakat untuk menabung atau mengambil pembiayaan pada lembaga keuangan baik syariah atau konvensional.

Hasil kuesioner memperlihatkan beberapa alasan masyarakat untuk menjadi mitra atau nasabah dari lembaga keuangan syariah. Pertama, karena ada 
keyakinan terhadap ajaran Islam untuk mendapatkan harta dan menginvestasikannya secara halal. Setelah diadakan survey terhadap 163 responden yang menjadi nasabah bank syariah didapati bahwa mayoritas atau 45.4\% responden yang memilih lembaga keuangan syariah karena produknya halal atau bebas dari riba. Selanjutnya mereka didorong oleh karena dekatnya kantor bank syariah dengan tempat mereka bekerja atau sebanyak $24.5 \%$, dan banyak juga karena dipengaruhi oleh perintah atasannya yang mengharuskan membuka rekening di bank syariah untuk kepentingan transfer gaji yaitu sebanyak $12 \%$ dari total responden. Motif lainnya adalah karena menganggap dari kewajiban menjalankan ajaran Islam, tabungan dan pembiayaan pada bank syariah sesuai kebutuhan, pelayanan yang nyaman dan memuaskan, serta karena ada tawaran bonus yang besar adalah motif yang sangat kecil dengan persentase di bawah $10 \%$.

Tabel 1. Alasan masyarakat menjadi nasabah Bank Konvensional

\begin{tabular}{|c|c|c|c|}
\hline Nasabah & Alasan & Frekuensi & Persentase \\
\hline \multirow{10}{*}{$\begin{array}{l}\text { Nasabah Bank } \\
\text { Konvensional }\end{array}$} & Bank Syariah sama dengan bank & 69 & 46.6 \\
\hline & konvensional (masih ada riba) & & \\
\hline & $\begin{array}{l}\text { Pelayanannya nyaman } \\
\text { memuaskan }\end{array}$ & 10 & 06.8 \\
\hline & Banknya dekat dengan tempat kerja & 19 & 12.8 \\
\hline & Ketersedian ATM yang merata & 31 & 20.9 \\
\hline & $\begin{array}{l}\text { Tabungan/kredit sesuai yang } \\
\text { dibutuhkan }\end{array}$ & 8 & 05.4 \\
\hline & Belum mengetahui ada bank syariah & 1 & 00.7 \\
\hline & Perintah atasan & 8 & 05.4 \\
\hline & Tawaran bunga dan bunos besar & 2 & 01.4 \\
\hline & Total & 148 & 100 \\
\hline
\end{tabular}

Sumber: Data setelah diolah melalui program SPSS

Sementara nasabah yang memilih bank konvensional sebagai tempat bermuamalah karena beralasan bahwa bank syariah masih terdapat riba atau tidak ada perbedaan pada keduanya. Dari 148 responden yang memiliki tabungan dan pembiayaan pada bank konvensional sebanyak 46.6\% menganggap bank Islam belum bebas riba, kemudian diikuti oleh $20.9 \%$ beralasan pada tingkat ketersediaan ATM yang lebih merata dan 12.8\% karena dekat dengan tempat bekerja. Selebihnya karena alasan pada pelayanan, sesuai kebutuhan, belum 
mengetahui adanya bank syariah, perintah atasan, dan tawaran bonus tidak terlalu menjadi motif bagi masyarakat kota Langsa dengan tingkat persentase dibawah 6\%. Secara lebih jelas dapat dilihat pada tabel 3 dibawah ini.

Jika kita lihat pandangan masyarakat terhadap lembaga keuangan syariah terkait dengan pelaksanaan syariat Islam di Aceh, maka lebih dari 61\% dari 213 responden menyatakan sudah sejalan dengan kebijakan pemerintah Aceh untuk menerapkan syariat Islam. Meskipun demikian 27\% lebih menyatakan tidak sejalan dan 11\% lebih menyatakan ragu-ragu. Hal ini sesuai dengan tingkat persentase responden yang menjadi nasabah lembaga keuangan syariah, ditambah dengan persepsi masyarakat yang masih banyak menganggap bank syariah sama dengan bank konvensional yaitu 46\% responden.

Meskipun demikian masyarakat meyakini bahwa tingkat komitmen lembaga keuangan Syariah dalam menerapkan prinsip-prinsip syariah dalam produknya sudah sejalan dengan syariat Islam. Masyarakat kota Langsa mampersepsikan komitmen lembaga keuangan syariah sebanyak 49.9\% atau 102 responden menyatakan ada komitmen, 19.7\% agak berkomitmen dan 2.8\% menjawab sangat berkomitmen. Sementara $26.3 \%$ menyatakan kurang berkomitmen dan hanya 3.3\% menyatakan tidak ada komitmen sama sekali.

Pada umumnya masyarakat juga merasa masih kurang faham dengan produk lembaga keuangan syariah yaitu sebanyak 31\% menyatakan kurang faham bahkan $10.3 \%$ merasa tidak faham sama sekali terhadap produk yang terdapat pada lembaga keuangan syariah. Hanya 28.6\% menyatakan faham dan $10.3 \%$ sangat faham, dan selebihnya 19.7\% menyatakan agak faham. Selanjutnya bila kita lihat dari 5 kelompok masyarakat yang kurang faham terhadap produk perbankan syariah adalah kelompok mahasiswa dan akademisi, selanjutnya para politisi dan lainnya. Sementara kelompok pedagang mayoritas menyatakan faham dan sangat faham dengan produk yang terdapat pada perbankan syariah.

Pemahaman masyarakat terhadap konsep maqashid syariah yaitu tujuan syariah untuk terlindunginya agama, jiwa, akal, keluarga, dan harta sangat bervariatif. Meskipun mayoritas atau 28.2\% menjawab faham dan 18.3\% sangat faham, tapi jumlah yang tidak faham juga mencapai $25.4 \%$, bahkan $16.4 \%$ tidak faham sama sekali dan $11.7 \%$ agak faham. Ini menunjukkan mayoritas masyarakat 
kota Langsa belum familiar dengan konsep maqashid Syariah. Persentase yang faham dan sangat faham besar kemungkinan dari kalangan akademisi dan mahasiswa yang pernah mengambil mata kuliah ushul fiqh. Dari sini masyarakat perlu sosialisasi tentang konsep maqashid syariah sehingga memiliki pemahaman tentang hikmah dari syariat Islam.

\section{Gambar 1. Pemahaman Terhadap Produk Perbankan Syariah.}

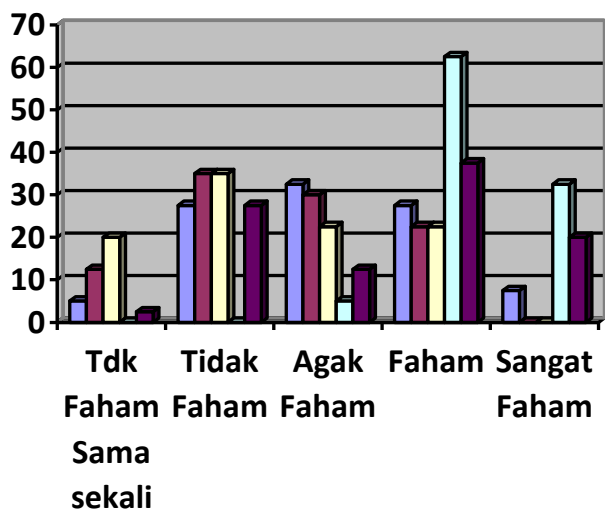

\begin{tabular}{|l|}
\hline Politisi \\
$\square$ Mahasiswa \\
$\square$ Akademisi \\
$\square$ Pedagang \\
$\square$ Lainnya \\
\hline
\end{tabular}

Hal yang menggembirakan tentu saja ketika melihat tingkat kepedulian masyarakat terhadap perlunya menjaga atau mencapai tujuan syariah itu sangat tinggi lebih dari 54\% responden menjawab sangat peduli dan 33\% lebih menyatakan peduli. Dibawah 1\% menjawab tidak peduli sama sekali, hanya 3.3\% menyatakan tidak peduli dan 6.6\% agak peduli. Disini menunjukkan masyarakat kota Langsa sesungguhnya sangat ingin mencapai tujuan syariat dalam hidupnya baik dalam ibadah maupun dalam bermuamalah. Namun karena sistem dan pendidikan yang berlaku masih dominan pemikiran sekuler terutama yang pendidikannya dari jalur umum. Secara alam bawah sadar masyarakat kita memiliki komitmen untuk menjalankan ajaran Islam dalam seluruh aktifitasnya. Disinilah peran pemerintah berpeluang untuk menerapkan seluruh sistem kehidupan sejalan dengan tuntunan syariat terutama perekonomian dan keuangan, sehingga realisasi tujuan syariat dapat mencapai level yang lebih baik.

Hasil kuesioner menampilkan tingkat realisasi tujuan syariah dalam aspek perlindungan agama dalam empat sektor yaitu tabungan nasabah bank Syariah, tabungan nasabah bank konvensional, nasabah penerima pembiyaan produktif dan konsumtif bank syariah. Nasabah penabung konvensional dan syariah terlihat 
hampir tidak ada perbedaan dimana mayoritas dapat menjalankan ibadah secara baik artinya tingkat ketenangan ibadah tidak terganggu yang sudah mencapai 52\% pada nasabah konvensional dan $58.5 \%$ pada nasabah syariah. Namun mayoritas pengambil pembiayaan pada bank syariah merasa capaian perlindungan agama masih pada level cukup yaitu $54 . \%$ pada pembiayaan produktif dan $50 \%$ pada pembiayaan konsumtif. Ini artinya mayoritas masih kurang mendapatkan kenyamanan dalam menjalankan ibadah. Meskipun demikian sebanyak 39.5\% nasabah pembiayaan konsumtif syariah telah merasakan baik dan 8.8\% sudah mencapai level sangat baik. Sementara nasabah produktif dan konsumtif konvensional mayoritas masih berada pada level kurang mencukupi yaitu 56\% produktif dan 50\% konsumtif. Sementara level baik 31\% produktif dan 30\% konsumtif dengan nilai mean 2.4 pada skala 1-5 likert.

Tabel 2. Pemahaman terhadap konsep \& kepedulian Maqashid Syariah

\begin{tabular}{llcc}
\hline \multicolumn{2}{c}{ Variabel } & Frekuensi & Persentase \\
\hline Pemahaman masyarakat & Tidak faham sama sekali & 35 & 16.4 \\
terhadap konsep Maqashid & Kurang faham & 54 & 25.4 \\
Syariah & Agak faham & 25 & 11.7 \\
& Faham & 60 & 28.2 \\
& Sangat faham & 39 & 18.3 \\
& Total & $\mathbf{2 1 3}$ & $\mathbf{1 0 0}$ \\
\hline Tingkat kepedulian & Tidak peduli sama sekali & 2 & 0.9 \\
masyarakat terhadap & Kurang peduli & 8 & 3.8 \\
kemaslahatan untuk & Agak peduli & 14 & 6.6 \\
menjaga Agama, jiwa, akal, & Peduli & 72 & 33.8 \\
keluarga dan harta & Sangat peduli & 117 & 54.8 \\
& Total & $\mathbf{2 1 3}$ & $\mathbf{1 0 0}$ \\
\hline
\end{tabular}

Sumber: Data setelah diolah dari program SPSS

Masyarakat kota Langsa secara umum menyambut positif keberadaan lembaga keuangan syariah dengan menyatakan bank Syariah perlu dikembangkan yang hampir mencapai 90\% dari total 213 responden baik nasabah konvensional maupun nasabah syariah. Meskipun ada 4.2\% menyatakan tidak perlu dan $6.6 \%$ menyatakan ragu-ragu. Pandangan pada perlunya pengembangan bank syariah adalah aspek positif pandangan masyarakat. meskipun masyarakat masih banyak yang menganggap bank syariah sebagai lembaga yang tidak bisa menghindari riba secara murni. 
Tabel 3. Persepsi Masyarakat Tentang Lembaga Keuangan Syariah

\begin{tabular}{llcc}
\hline \multicolumn{1}{c}{ Variabel } & & Frekuensi & Persentase \\
\hline Lembaga keuangan Syariah perlu & Ya & 190 & 89.2 \\
dikembangkan & Tidak & 9 & 4.2 \\
& Ragu-ragu & 14 & 6.6 \\
& Total & $\mathbf{2 1 3}$ & $\mathbf{1 0 0}$ \\
\hline Lembaga keuangan syariah telah & Ya & 150 & 70.4 \\
memberi dampak positif terhadap & Tidak & 32 & 15 \\
pembangunan ekonomi di Kota & Rag-ragu & 31 & 14.6 \\
Langsa & Total & $\mathbf{2 1 3}$ & $\mathbf{1 0 0}$ \\
\hline
\end{tabular}

Sumber: Data setelah diolah melalui program SPSS

Kehadiran lembaga keuangan Islam di Kota Langsa pada level yang paling minimal telah mendorong aktifitas ekonomi secara positif artinya semakin banyak lembaga yang memfasilitasi modal maka akan semakin terbuka peluang bagi masyarakat untuk terlibat dalam aktifitas ekonomi maka semakin baik, sepanjang tujuan dari prosesnya sesuai dengan ajaran Islam yaitu mencapai falah dan maslahah. Semakin produktif seorang muslim maka akan semakin sejahtera hidupnya dan kesejahteraanya akan semakin mendekatkan kepada Allah swt sehingga kebahagiaan dunia dan akhirat dapat diraihnya.

\section{SIMPULAN}

Hasil kajian ini telah mengungkapkan bahwa masyarakat yang tidak mau atau sepenuhnya mau menjadi nasabah lembaga keuangan syariah dikarenakan mereka masih mempersepsikan bahwa masih terdapatnya riba dalam sistem lembaga keuangan Islam. Hal ini juga tidak terlepas dari masih banyak masyarakat yang kurang memahami produk yang terdapat pada lembaga keuangan syariah terutama kelompok mahasiswa, politisi, akademisi, dan lainnya. Sementara para pedagang mayoritas memahami produk lembaga keuangan syariah. Namun demikian orientasi profit dan tingkat kemudahan yang ditawarkan oleh lembaga keuangan konvensional masih lebih nyaman dibandingkan dengan lembaga keuangan syariah yang menyebabkan banyak pedagang juga belum menjadi nasabah lemabga keuangan syariah. Masyarakat kota Langsa pada umumnya mempersepsikan kehidiran lembaga keuangan Syariah telah memberi stimulus terhadap pertumbuhan ekonomi, dengan adanya tingkat investasi akan membuka 
peluang bisnis dan pengurangan tenaga kerja. Meskipun demikian penelitian ini belum mampu memberikan gambaran lebih detail berapa kontribusi lebaga keuangan syariah dalam pertumbuhan ekonomi di Kota Langsa. Maka dibutuhkan penelitian lanjutan guna mengungkap peran lembaga ekonomi Syariah secara lebih detail.

\section{PUSTAKA ACUAN}

Al Arif, M.N.R. (2012). Lembaga Keuangan Syariah: Kajian Teoritis Praktis. Bandung: Pustaka Setia.

Antonio. M.S. (2001). Bank Syariah: Teori dan Praktik. Jakarta: Gema Insani Press.

Daulay, Y. (2014). Analisis Faktor-Faktor yang Mempengaruhi Persepsi Masyarakat Propinsi Banten Terhadap Perbankan Syariah. (Laporan Penelitian). Jakarta: Universitas Prof. Dr. Hamka.

Huda, N. \& M. Heykal. (2010). Lembaga Keuangan Islam Tinjauan Teoretis dan Praktis. Jakarta: Prenada Media Group.

Karim, A.A. (2003). Bank Islam: Analisis Fiqih dan Keuangan. Jakarta: IIITIndonesia.

Khaldi, M.A. (2002). Persepsi Masyarakat Tentang Bank Islam di Kabupaten Bogor. (Tesis Tidak Dipublikasikan). Institut Pertanian Bogor.

Mannan, A. (1997). Teori dan Praktek Ekonomi Islam. Yogyakarta Dana Bhakti Wakaf.

Mu'allim, A. (2003). Persepsi Masyarakat Terhadap Lembaga Keuangan Syariah. AlMawardi. Vol. X: 71-80.

Reni, A. \& N.H. Ahmad. (2016). Application of Theory Reasone Action in Intention to Use Islamic Baking in Indonesia. Journal of Al-Iqtishad: Jurnal Ilmu Ekonomi Syariah (Journal of Islamic Economics). Vol. 8 (1): 137-148.

Saeed, A. (2004). Bank Islam dan Bunga: Studi Kritis Interpretasi Kontemporer Tentang Riba dan Bunga. Yogyakarta: Pustaka Pelajar.

Sari, I.M, dkk. (2015). Factors That Influenced People to Become Islamic Bank Customer: A Study on Kancana Villagers. Journal of Al-Iqtishad: Jurnal Ilmu Ekonomi Syariah (Journal of Islamic Economics). Vol. 7 (1): 73-86. 
Tim Pengembangan Perbankan Syariah Institute Bankir Indonesia. (2003). Konsep, Produk dan Implementasi Operasional Bank Syariah. Jakarta: Djambatan.

Usman, H. (2015). The Role of Religious Norms on Selecting Islamic Bank. Journal of Al-Iqtishad: Jurnal Ilmu Ekonomi Syariah (Journal of Islamic Economics). Vol. 7 (1): 31-44.

Widigdo, A.M.N. dkk. (2016). Business Process Reengineering of Funding on Indonesia's Islamic Banks. Journal of Al-Iqtishad: Jurnal Ilmu Ekonomi Syariah (Journal of Islamic Economics). Vol. 8 (1): 19-32. 